\title{
THE APPLICATION OF CLASSICAL AND NEURAL REGRESSION MODELS FOR THE VALUATION OF RESIDENTIAL REAL ESTATE
}

Łukasz Mach, Ph.D.

Opole University of Technology

Faculty of Economics and Management

Department of Economics, Finances and Regional Research

Luboszycka 7, 45-036 Opole, Poland

e-mail:l.mach@po.opole.pl

\begin{abstract}
The research process aimed at building regression models, which helps to valuate residential real estate, is presented in the following article. Two widely used computational tools i.e. the classical multiple regression and regression models of artificial neural networks were used in order to build models. An attempt to define the utilitarian usefulness of the above-mentioned tools and comparative analysis of them is the aim of the conducted research. Data used for conducting analyses refers to the secondary transactional residential real estate market.
\end{abstract}

Keywords: real estate, residential property, multiple regression, neural regression, valuation

JEL classification: C45, C51, R32 


\section{Introduction}

The characteristics of the residential real estate market implies difficulties in the compilation of one universal method of housing stock valuation. It is the result of the considered issue's complexity which is manifested in a multitude of potential dimensions of analysis. Factors which affect the value of the apartment can be considered in terms of the whole economy, region's economy or even the particular apartment. Naturally, during the estimation the value of real estate, we apply a different approach to the so-called resource luxury, typical or low-quality resource. Another important issue, in the process of estimating the value of residential real estate and the characteristics defining it, is the choice of the calculation method. In this aspect, the question arises whether the use of the method based on the classical analysis of an economicstatistical correlation is an effective and sufficient approach. Is it possible to check and apply one of the alternative methods like e.g. method based on the application of artificial intelligence? Considering the above mentioned issues, two models of the valuation of residential real estate, are presented in this article. The first one is the multiple regression model and the second one is the neural regression model. After building models which specify the value of residential real estate, their usefulness in their practical application was checked and a comparative analysis of them was conducted. Data was used to estimate the value of the housing stock based on transactional data, which derives from the regional real estate market. It is assumed that the built models would be useful for estimating the value of typical (average) housing stock. It should also be noted that the implementation of the research described in this article is located in one of the many research dimensions in the area of the real estate market. In the literature, we can find papers referring e.g. to the increase of residential value caused by the division of the property and the construction of technical infrastructure (Dawid, 2014), analysis of the resistance line and its impact on residential price (Gdakowicz, 2014), the formation of the structure of investment in real estate (Zygmunt, 2013), analysis of the development possibilities of the construction industry (Zygmunt, Szewczyk, 2011), the construction of dynamic models of real estate (Zyga, 2012) and the construction of an integrated model which determine the logarithm of the price of a square meter (Mach, 2014) or an analysis of real estate for large datasets (Kubus 2016) and the use of a regression (Rącka, 2016; Mach, 2011) and quantile regression in the analysis of the real estate market (Widłak, Nehrebecka, 2011). At the end of the introduction it should be noted that in the literature we can find a lot of articles describing the use of artificial intelligence in the economic area (e.g. Chiarazzo, Caggiani, Marinelli, Ottomanelli, 2014; Limsombunchai, Gan, 
Lee, 2004; Ma, Chen, Zhang, 2015; Sampathkumar, Santhi, Vanjinathan, 2015; Soni, Sadiq, 2015; Ripley, 1994; Brockett, Golden, Jang, Yang, 2006; Hurrion, Birgil, 1999).

\section{Implementation of the research process - preliminary analysis}

The research process aimed at building regression models, which determine the price of a square meter of residential real estate, was conducted in two stages. In the first stage a classical model of multiple regression was built. It enabled to indicate variables, which significantly affect the price of a square meter of real estate. Whereas in the second stage, taking into account variables used in the classical multiple regression model, the process of building neural regression models was conducted. Also the action of the built regression models was examined indicating the utilitarian aspects of their application. Data was aimed at building regression models concerned the secondary transactional real estate market. In the process of building classical regression models the calculation methodology described inter alia in the works of Aczel (2000), Dziechciarz (2003), Gruszczyński (2009), Maddala (2008), while building neuron models in works inter alia Duch (2000), Ossowski (2000), Rutkowski (1997), Tadeusiewicz (1997) were commonly used.

In the built model data referring to the sales of apartments in Opole in 2015 were taken into account and data derived from the Department of Geodesy and Cartography of the Municipality of Opole. The database deriving from the Department of Geodesy and Cartography enabled collecting the attributes of sold apartments such as: Y - price of apartment (PLN), X1 - the floor area (square meters), X2 - number of rooms (pieces), X3 - floor on which the apartment is located (number), X4 - the date of the transaction (date day-month-year), X5 - ownership right (ownership, cooperative ownership right to the premises), X6 - type of kitchen (bright, dark, kitchen annexe), X7 - external surface (yes/no) X8 - assessment of apartment location (favourable, average, not so favourable), X9 - year of construction (number), X10 - number of floors (number) and X11 - assessment of the building's location (favourable, average, not so favourable). Complementary activities to the above mentioned research procedure were inter alia coding and tabulating of the collected data, elimination of outlining data and testing the distribution of researched variables. At the stage of data encoding variable $\mathrm{Y}$ - price per square meter of apartment was defined as a dependent variable whereas other variables were classified as independent. Researching the distribution of variable $\mathrm{Y}$, the value of the test statistics Ch-square test was calculated and for the level of significance defined at the $5 \%$ level the null hypothesis referring to the compatibility distribution of the researched variables with normal 
distribution was rejected. ${ }^{1}$ Due to this fact, a new variable was created i.e. natural logarithm of the price per square meter of apartment, for which there was obtained the compatibility of researched characteristics distribution with normal distribution. ${ }^{2}$ A division was made (classification) referring the year of the construction of buildings i.e. for apartments built up to 1949, apartments built from 1950-1960, in the years 1966-1996 and in the years 1997-2015. An attribute describing the number of stories was divided into buildings with less than 5 stories, and apartments located in buildings with more than 5 stories. The number of obtained records was at the level of 436 including 30 records which were marked as test data (useful to check the utilitarian properties of the built models). In Table 1 below there is a list of apartment attributes, which potentially affect the price of square meter of housing resource with particular consideration to the qualitative variables which are presented. Codes of variables and their attributes listed in Table 1 were the starting point for the construction of the classical model of multiple regression.

Table 1. Names applied in building regression models

\begin{tabular}{|c|c|}
\hline Code of variable & Attribute of apartment (variable) \\
\hline 1 & 2 \\
\hline $\mathrm{Y}$ & price of square meter of an apartment \\
\hline $\ln (\mathrm{Y})$ & logarithm of the price per square meter of an apartment \\
\hline $\mathrm{X} 1$ & floor area of an apartment \\
\hline $\mathrm{X} 2$ & logarithm of floor area of an apartment \\
\hline $\mathrm{X} 3$ & number of rooms \\
\hline $\mathrm{X} 4$ & floor on which the apartment is located \\
\hline $\mathrm{X} 5$ & transaction date \\
\hline $\mathrm{X} 6$ & ownership \\
\hline $\mathrm{X} 7$ & co-operative ownership to the residential premises \\
\hline $\mathrm{X} 8$ & bright kitchen \\
\hline X9 & kitchen annex \\
\hline $\mathrm{X} 10$ & dark kitchen \\
\hline $\mathrm{X} 11$ & external surface-yes \\
\hline $\mathrm{X} 12$ & external surface-no \\
\hline $\mathrm{X} 13$ & assessment of apartment location - favourable \\
\hline $\mathrm{X} 14$ & assessment of apartment location - average \\
\hline $\mathrm{X} 15$ & assessment of apartment location - not so favourable \\
\hline $\mathrm{X} 16$ & year of the building's construction \\
\hline $\mathrm{X} 17$ & years up to 1949 \\
\hline $\mathrm{X} 18$ & years $1950-1965$ \\
\hline $\mathrm{X} 19$ & years 1966-1996 \\
\hline $\mathrm{X} 20$ & years 1997-2015 \\
\hline
\end{tabular}

\footnotetext{
1 The variable Y, Chi-square $=49.45181, \mathrm{df}=5$ (fit.), $\mathrm{p}=0.00000$.

2 The variable $\ln (\mathrm{Y})$, Chi-square $=10.45432, \mathrm{df}=5$ (fit.), $\mathrm{p}=0.06334$.
} 


\begin{tabular}{|l|l|}
\hline 1 & \\
\hline X21 & number of building stories \\
\hline X22 & number of stories $\leq 5$ \\
\hline X23 & number of stories $>5$ \\
\hline X24 & prefabricated construction technology \\
\hline X25 & traditional construction technology \\
\hline X26 & traditional construction technology refined \\
\hline X27 & building location - favourable \\
\hline X28 & building location - average \\
\hline X29 & building location - not so favourable \\
\hline
\end{tabular}

Source: own study.

\section{Implementation of the research process - classic model of multiple regression}

Construction of the classical model of multiple regression based on the application of stepwise regression. In the process of the selection of statistically insignificant variables, commonly used rule of their elimination i.e. the highest value of the parameter $p^{3}$ was applied. A model after the first estimation of the parameters had the form as presented in Table 2.

Table 2. Estimation of the model using $\mathrm{LSM}^{4}$ (standard errors of parameters according to resistant heteroscedasticity, variant HC1)

\begin{tabular}{|l|c|c|c|}
\hline \multicolumn{1}{|c|}{ Attribute of apartment (variables) } & Coefficients & Stand. error & p-value \\
\hline Const. & 8.06792 & 0.105243 & $<0.0001$ \\
\hline Floor area of apartment & -0.00430 & 0.000995 & $<0.0001$ \\
\hline Number of rooms & 0.04480 & 0.019554 & 0.0225 \\
\hline Floor on which the ap. is located & 0.00335 & 0.005293 & 0.5263 \\
\hline Right to ownership - ownership & 0.03213 & 0.032846 & 0.3285 \\
\hline Dark kitchen & -0.02036 & 0.030426 & 0.5036 \\
\hline External surface-yes & -0.003713 & 0.021183 & 0.8610 \\
\hline Assessment of apar. location - favourable & 0.07329 & 0.025353 & 0.0041 \\
\hline Assessment of apartment location - average & 0.04503 & 0.021156 & 0.0339 \\
\hline Year of the building (up to 1949) & -0.12839 & 0.089088 & 0.1503 \\
\hline Year of the building (1950-1965) & -0.07735 & 0.087615 & 0.3778 \\
\hline Year of the building (1966-1996) & -0.00857 & 0.084904 & 0.9196 \\
\hline Number of stories $\leq 5$ & 0.05150 & 0.030548 & 0.0926 \\
\hline Traditional construction technology refined & 0.15115 & 0.084653 & 0.0750 \\
\hline Building location - favourable & 0.21358 & 0.035015 & $<0.0001$ \\
\hline Building location - average & 0.14492 & 0.038209 & 0.0002 \\
\hline
\end{tabular}

Source: own study.

\footnotetext{
3 Excluding constant value.

4 LSM - Least Squares Method.
} 
Table 3. Parameters defining the quality of the built model

\begin{tabular}{|l|c|}
\hline \multicolumn{1}{|c|}{ Parameters of model } & The value of the parameter \\
\hline Arithmetic average of the dep. variable & 8.224433 \\
\hline Sum of squared & 9.892701 \\
\hline Coefficient of the determination of R-square & 0.451104 \\
\hline F(15.389) & 27.19152 \\
\hline The standard deviation of the dep. variable & 0.211214 \\
\hline Square error of residues & 0.159471 \\
\hline Adjusted coefficient of determination & 0.429938 \\
\hline p-value (F test) & $1.61 \mathrm{e}-51$ \\
\hline
\end{tabular}

Source: own study.

Analysing the results of the estimation of the first regression model, we can see that 6 variables are statistically significant. Parameters defining the quality of the built model are shown in Table 3. In the next stages of building the regression model variables such as: year of construction of the building - 1966-1996, balcony as an attribute of the apartment, floor on which the apartment is located, dark kitchen, the ownership of the apartment and the number of stories, were eliminated. The parameters of the obtained model are presented in Tables 4 and 5 .

The model $^{5}$ coefficient of determination equal to 0.45 is significantly significant. Conducting the process of the verification of the model residuals it was demonstrated that the distribution of residuals is not compatible with the normal distribution and this model has an incorrect specification. Continuing the process of building the model, furthermore, the inter alia data marked as outliers were removed and the variable floor area was converted into a variable logarithm of the floor area. Parameters of the final classical regression model were placed in Tables 6 and 7. For the model described in Table 6, the process of checking the quality of the model gave acceptable results. ${ }^{6}$ This model was used to determine the price per square meter of residential real estate.

\footnotetext{
5 Value $\mathrm{p}$ for test $\mathrm{F}<0.05$.

6 1. Test for non-linearity. The null hypothesis: the relationship is linear. The test statistic: $L M=1.59291$ with a value of $p=P($ Chi-square $(1)>1.59291)=0.20691 .2$. Test RESET for the specification. The null hypothesis: specification correct. The test statistics: $F(2.344)=0.0076156$ with value $p=P(F(2.344)>0.00761561)=0.992413$. 3. White's test for the heteroskedasticity residuals. The null hypothesis: heteroskedasticity residuals does not occur. The test statistics: $L M=25.7938$ with a value $p=P($ Chi-square $(24)>25.7938)=0.36371 .4$. Test for normality layout of residuals. Null hypothesis: the random component has a normal layout. Test statistics: Chi-square $(2)=0.94889$ with a value of $p=0.62223$. 5. Evaluation of collinearity $V I F(\mathrm{j})$ - variance inflation factor: logarithm of the surface $=1.042$, the location of the apartment in the building - favorable $=1.535$, the location of the apartment in the building - average $=1.548$, year of the construction of the building until $1949=1.228$, construction technology of building - traditional refined $=1.171$, location of apartment in residential district - favourable $=4.977$, location of apartment in residential district - average $=4.996$.
} 
Table 4. Estimation of the model with the use of LSM (standard errors of parameters according to the resistant heteroscedasticity, variant $\mathrm{HC} 1$ )

\begin{tabular}{|l|c|c|c|}
\hline \multicolumn{1}{|c|}{ Attribute of apartment (variables) } & Coefficients & Stand. error & p-value \\
\hline Const. & 8.13973 & 0.043550 & $<0.0001$ \\
\hline Floor area of apartment & -0.00425 & 0.000982 & $<0.0001$ \\
\hline Number of rooms & 0.04434 & 0.019417 & 0.0229 \\
\hline Assessment of apartment location - favourable & 0.07488 & 0.025036 & 0.0030 \\
\hline Assessment of apartment location - average & 0.04867 & 0.018852 & 0.0102 \\
\hline Year of the building (up to 1949) & -0.09992 & 0.023688 & $<0.0001$ \\
\hline Year of the building (1950-1965) & -0.05570 & 0.024157 & 0.0216 \\
\hline Traditional construction technology refined & 0.17709 & 0.021159 & $<0.0001$ \\
\hline Building location - favourable & 0.19717 & 0.034576 & $<0.0001$ \\
\hline Building location - average & 0.12720 & 0.037134 & 0.0007 \\
\hline
\end{tabular}

Source: own study.

Table 5. The parameters defining the quality of the constructed model

\begin{tabular}{|l|c|}
\hline \multicolumn{1}{|c|}{ Model parameters } & The value of the parameter \\
\hline Arithmetic average of the dependent variable & 8.224433 \\
\hline Sum squared & 9.976409 \\
\hline Coefficient of the determination of R-square & 0.446459 \\
\hline F(15.389) & 38.02704 \\
\hline The standard deviation of the dep. variable & 0.211214 \\
\hline Square error of residues & 0.158924 \\
\hline Adjusted coefficient of determination & 0.433847 \\
\hline p-value (F test) & $2.01 \mathrm{e}-48$ \\
\hline
\end{tabular}

Source: own study.

Table 6. Model estimation with the application of MLS

(standard errors of parameters according to resistant heteroscedasticity, variant HC1)

\begin{tabular}{|l|c|c|c|}
\hline \multicolumn{1}{|c|}{ Attribute of apartment (variables) } & Coefficients & Stand. error & p-value \\
\hline Const. & 8.62705 & 0.117956 & $<0.0001$ \\
\hline Logarithm of floor area of an apartment & -0.14669 & 0.028807 & $<0.0001$ \\
\hline Assessment of apartment location - favourable & 0.056186 & 0.021996 & 0.0111 \\
\hline Assessment of apartment location - average & 0.041483 & 0.017547 & 0.0186 \\
\hline Year of the building (up to 1949) & -0.09334 & 0.017172 & $<0.0001$ \\
\hline Traditional construction technology refined & 0.15509 & 0.019084 & $<0.0001$ \\
\hline Building location - favourable & 0.15314 & 0.027828 & $<0.0001$ \\
\hline Building location - average & 0.11521 & 0.031838 & 0.0003 \\
\hline
\end{tabular}

Source: own study. 
Table 7. Parameters defining the quality of the built model

\begin{tabular}{|l|c|}
\hline \multicolumn{1}{|c|}{ Parameters of model } & The value of the parameter \\
\hline Arithmetic average of the dependent variable & 8.233408 \\
\hline Sum squared & 5.868687 \\
\hline Coefficient of the determination of R-square & 0.411716 \\
\hline F(15.389) & 36.17474 \\
\hline The standard deviation of the dep. Variable & 0.168109 \\
\hline Square error of residues & 0.130236 \\
\hline Adjusted coefficient of determination & 0.399815 \\
\hline p-value (F test) & $7.85 \mathrm{e}-38$ \\
\hline
\end{tabular}

Source: own study.

\section{Research process implementation - neural regression model}

The starting point for the construction of the neural regression model was the choice of explanatory variables. It was made from an assumption that in the neural model the explanatory variables are variables classified as significant in the classical regression model (see Table 6). In the process of the division of the data set for the train, test and validation data the structure was applied accordingly 70,15 and 15\%. For the construction of neural models two types of networks were used i.e. a multi-layer perceptron network (MLP) and a radial basis function network $(\mathrm{RBF})$. Limiting the criteria which were applied in the process of train networks referred to the minimum and maximum number of hidden layers. In the MLP network in the hidden layer and output layer activation functions were applied: linear, logistic, hyperbolic-tangent and exponential. The train algorithm of perceptron network is a Quasi-Newton algorithm. In the case of networks with a radial basis function, activation functions in the hidden layer are isotropic Gaussian functions. In RBF networks the activation function is a linear function. The error value calculated for applied neural networks is the sum of residuals squares (SOS). In Table 8 the parameters of 5 neural networks, which obtained the best results of train, test and validation, are presented. All of the obtained networks are multilayer perceptions with 11 neurons in the input layer and 1 neuron in the output layer. In Table 8 there were additionally placed qualitative network parameters which were obtained in the process of train, test and validation as well as type of activation function in the hidden and output layer. All of the selected networks are characterized by similar qualitative properties. The best indicator of the train characterized network no. 4 i.e. MLP 11-7-1 with a logistic and exponential activation function that has been selected for further processing utilitarian test its operation. 
Table 8 . The best selected neural models

\begin{tabular}{|l|c|c|c|c|c|}
\hline Neural network & $\begin{array}{c}\text { Quality } \\
\text { of learning }\end{array}$ & $\begin{array}{c}\text { Quality } \\
\text { of testing }\end{array}$ & $\begin{array}{c}\text { Quality } \\
\text { of valid. }\end{array}$ & $\begin{array}{c}\text { Activation function } \\
\text { (hidden layer) }\end{array}$ & $\begin{array}{c}\text { Activation function } \\
\text { (output layer) }\end{array}$ \\
\hline MLP 11-7-1 & 0.53 & 0.56 & 0.66 & tanh & tanh \\
\hline MLP 11-11-1 & 0.54 & 0.54 & 0.64 & exponential & logistic \\
\hline MLP 11-10-1 & 0.55 & 0.59 & 0.63 & tanh & exponential \\
\hline MLP 11-7-1 & 0.55 & 0.58 & 0.68 & logistic & Tanh \\
\hline MLP 11-10-1 & 0.55 & 0.55 & 0.65 & logistic & \\
\hline
\end{tabular}

Source: own study.

\section{Analysis of the results, regression models and discussion}

The summarizing stage of the research was the verification of the practical utility of the regression models and their comparative analysis. The procedure of testing the classical and neural models was conducted on the new input data. The measure verifying the quality of the regression models was the criterion of minimizing the value of the mean absolute percentage error. For particular models there were calculated: mean absolute percentage errors (application of all data marked as testing data); mean absolute percentage errors with the division referring to the price of a square meter (the following ranges were defined: the price per square meter for transactions of apartments with a price of less than 3,000 PLN, the price of meter of apartment in the range of 3,000-3,500 PLN, the price of meter between 3,500-4,000 PLN, and ranges 4,000-4,500 PLN, 4,500-5,000 PLN, and the price per square meter of an apartment above 5,000 PLN); mean absolute percentage errors with a division for metric area of an apartment (for apartments smaller than 40 meters, for apartments with a floor area of 40-80 meters and for apartments larger than 80 meters); mean absolute percentage errors with the division of rooms numbers (included one-room apartments, two-rooms, three-rooms and four-room apartment). The classical regression model tested for all the test data obtained an average percentage error which equals $17.39 \%$, while the neural model error was $17.50 \%$. It can therefore be noted that altogether the tested models obtained very similar results (the difference was only 0.11 p.p.). The greatest variation in average error rates were obtained in models built for different price ranges. It can be noted that the model of classical regression obtained better results for apartments with the price per square meter below 3,500 PLN whereas the neural model gained an advantage in the case of estimating the price of a square meter of apartment exceeding 4,000 PLN per square meter. It is worth considering that the largest qualitative difference in the obtained models was noted for apartments with the price per square meter from the range of 4,500-5,000 PLN (see Table 9). Then the models where the criterion of identity of testing 
records was the total metric area of an apartment (see Table 10) and number of rooms in the apartment (see Table 11) were tested. In both considered criterion of identity, the results for the classic and neural regression models are very similar. The biggest error difference which can be observed is 2.19 p.p. and it takes a place while testing regression models including data referring to transactions of apartments with 4 rooms.

A summary of the research was the verification of the gravity of differences for mean absolute percentage errors obtained for the classical regression model and neural regression model. In total the gravity of 14 differences were researched i.e. for each comparable model. In each of 1 the 4 researched cases differences in means for classic and neural models were irrelevant. ${ }^{7}$

Table 9. Results obtained for the regression models, taking into account the price per square meter of residential real estate

\begin{tabular}{|c|c|c|c|}
\hline Price per square meter & Classical model & Neural model & Difference (p.p.) \\
\hline Apart. with a price of less than 3,000 PLN & 20.85 & 33.48 & 12.63 \\
\hline Apart. with a price between $3,000-3,500$ PLN & 12.07 & 18.84 & 6.77 \\
\hline Apart. with a price between $3,500-4,000$ PLN & 9.64 & 6.61 & 3.03 \\
\hline Apart. with a price between $4,000-4,500$ PLN & 13.94 & 4.92 & 9.02 \\
\hline Apart. with a price between $4,500-5,000$ PLN & 28.47 & 12.6 & 15.87 \\
\hline Apart. with a price Above 5,000 PLN & 43.00 & 35.39 & 7.61 \\
\hline Arice per square meter - all data & 17.39 & 17.5 & 0.11 \\
\hline
\end{tabular}

Source: own study.

Table 10. Results obtained for the regression models, including the price of total metric area of housing stock

\begin{tabular}{|l|c|c|c|}
\hline \multicolumn{1}{|c|}{ Area of apartment } & Classical model & Neural model & Difference (p.p.) \\
\hline Apartments smaller than 40 meters & 21.31 & 22.81 & 1.50 \\
\hline Apartments with a floor area of 40-80 meters & 13.96 & 13.26 & 0.70 \\
\hline Apartments larger than 80 meters & 18.48 & 17.46 & 1.02 \\
\hline
\end{tabular}

Source: own study.

Table 11. Results obtained for the regression models, including the number of rooms in the housing resource

\begin{tabular}{|c|c|c|c|}
\hline Number of rooms & Classical model & Neural model & Difference (p.p.) \\
\hline 1 & 23.37 & 22.20 & 1.17 \\
\hline 2 & 12.89 & 14.46 & 1.57 \\
\hline 3 & 19.44 & 18.00 & 1.44 \\
\hline 4 & 22.69 & 20.50 & 2.19 \\
\hline
\end{tabular}

Source: own study.

\footnotetext{
7 For testing the significance of the differences an analysis of variance was used.
} 


\section{Conclusions}

Research enabled checking the usefulness of the application of two types of decisionmaking models. The model based on the application of the multiple regression was the first one whereas the second one was the model using neural networks. Both models confirmed the usefulness of their application meaning the usefulness of estimating the logarithm of the price per square meter of residential property. A comparative analysis of the models showed that these models have similar predictive characteristics. The measure enabling a comparison of the models was a mean absolute percentage error. It is worth noting that differences in the mean absolute percentage errors for the researched cases turned out statistically insignificant.

\section{References}

Aczel, A.D. (2000). Statystyka w zarzadzaniu. Warszawa: Wydawnictwo Naukowe PWN.

Batóg, B., Foryś, I. (2011). Modele logitowe w analizie transakcji na warszawskim rynku mieszkaniowym. Studia i Materiały Towarzystwa Naukowego Nieruchomości, 3, 34-48.

Brockett, P.L., Golden, L.L., Jang, J., Yang, Ch. (2006). A Comparison of Neural Network, Statistical Methods, and Variable Choice for Life Insurers' Financial Distress Prediction. The Journal of Risk and Insurance, 73 (3), 397-419. DOI: 10.1111/j.15396975.2006.00181.x.

Chiarazzo, V., Caggiani, L., Marinelli, M., Ottomanelli, M. (2014). A Neural Network based Model for Real Estate Price Estimation Considering Environmental Quality of Property Location. Transportation Research Procedia, 3, 810-817. DOI: 10.1016/j.trpro.2014.10.067.

Dawid, L. (2014). Wzrost wartości nieruchomości na skutek podziałów nieruchomości i budowy urządzeń infrastruktury technicznej na przykładzie gminy Mielno. MOTROL Motoryzacja i Energetyka Rolnictwa, 16 (1), 19-24.

Duch, W. (2000). Sieci neuronowe. Polska Akademia Nauk. Warszawa: Wydawnictwo EXIT.

Dziechciarz, J. (2003). Ekonometria. Metody, przykłady, zadania. Wrocław: Wydawnictwo Akademii Ekonomicznej im. Oskara Langego we Wrocławiu.

Gdakowicz, A. (2014). Linia oporu a ceny mieszkań na rynku pierwotnym w wybranych miastach Polski. Studia i Prace WNEiZ US, 36 (2), 225-238.

Gruszczyński, M. (2009). Ekonometria i badania operacyjne. Warszawa: Wydawnictwo Naukowe PWN. 
Hurrion, R.D., Birgil, S. (1999). A Comparison of Factorial and Random Experimental Design Methdos for the Development of Regression and Neural Network Simulation Metamodels. The Journal of the Operational Research Society, 50 (10), 1018-1033.

Kubus, M. (2016). Locally regularized linear regression in the valuation of real estate. Statistic in Transation - new series, 17 (3), 1-10.

Limsombunchai, V., Gan, Ch., Lee, M. (2004). House Price Prediction: Hedonic Price Model vs. Artificial Neural Network. American Journal of Applied Sciences, 1 (3), 193-201. DOI: 10.3844/ajassp.2004.193.201.

Ma, H., Chen, M., Zhang, J. (2015). The Prediction of Real estate Price Index based on Improved Neural Network Algorithm. Advanced Science and Technology Letters, 81, 10-15. DOI: 10.14257/astl.2015.81.03.

Mach, Ł. (2011). Budowa praktycznego modelu regresji opisującego zależności występujące na rynku nieruchomości mieszkaniowych. Zeszyty Naukowe Wyższej Szkoły Bankowej we Wrocławiu. Metody ilościowe w ekonomii i Zarządzaniu, 20, 291-302.

Mach, Ł. (2014). Czynniki kształtujące wartość nieruchomości mieszkaniowych w kontekście uwarunkowań makro-, mikro- oraz ultraotoczenia, Ekonometria, 46, 52-61.

Maddala, G.S. (2008). Ekonometria. Warszawa: Wydawnictwo Naukowe PWN.

Ossowski, S. (2000). Sieci neuronowe do przetwarzania informacji. Warszawa: Oficyna Wydawnicza Politechniki Warszawskiej.

Rącka, I. (2016). Characteristics affecting housing process in Kalisz. Construction Entrepreneurship and Real Property, Proceedings of the 31th International Scientific and Practical Conference in November 2016 - Издателство „Наука И Икономика”, Икономически Университет, Варна (Varna).

Ripley, B.D. (1994). Neural Networks and Related Methods for Classification. Journal of the Royal Statistical Society. Series B (Methodological), 56 (3), 409-456.

Rutkowska, D. (1997). Sieci neuronowe, algorytmy genetyczne i systemy rozmyte. Warszawa: Wydawnictwo Naukowe PWN.

Sampathkumar, V., Santhi, M.H., Vanjinathan, J. (2015). Forecasting the Land Price Using Statistical and Neural Network Software. Procedia Computer Science, 57, 112-121. DOI: 10.1016/j.procs.2015.07.377.

Soni, A.K., Sadiq, A.A. (2015). Real Estate Valuation Using Artificial Neural Network (Ann). International Journal of Science, Technology \& Management, 4 (5).

Tadeusiewicz, R. (1997). Sieci neuronowe. Warszawa: Akademicka Oficyna Wydawnicza RM.

Widłak, M., Nehrebecka, N. (2011). Wykorzystanie regresji kwantylowej w analizie zróżnicowania cen mieszkań. Wiadomości Statystyczne, 5, 17-46.

Zyga, J. (2012). Model dynamiczny rynku i wartości nieruchomości. Studia i materiały Towarzystwa Naukowego Nieruchomości, 20 (1), 209-220. 
Zygmunt, A., Szewczyk, M. (2011). Możliwości rozwoju branży budowlanej w województwie opolskim. Barometr Regionalny. Analizy i Prognozy, 4 (26), 75-83.

Zygmunt, J. (2013). Kształtowanie się struktury inwestycji w nieruchomości na przykładzie województwa dolnośląskiego. Zeszyty Naukowe Wyższej Szkoły Bankowej we Wrocławiu, 5 (37). 